\title{
Online Learning in Covid-19 Pandemic: New Student Perspective at Islamic Religious Education Program
}

\author{
Suwarno', Edy Saputra², Kharisul Wathoni3, Muhammad Tamrin4, Amalia \\ Nur Aini5
}

DOI: 10.35445/alishlah.v13i2.951

\section{Article Info \\ Keywords: \\ Online Learning; \\ Covid-19 Pandemic; \\ New Student; \\ Islamic Education}

Kata kunci:

Pembelajaran Daring;

Pandemi covid-19;

Mahasiswa baru;

Pendidikan Agama

Islam

\section{Abstract}

New students for the 2020/2021 academic year have never experienced a direct meeting with the campus since registering, undergoing the orientation period, and lectures are all done online. This study aims to determine the opinion of new students of the Islamic Religious Education study program towards the lectures they undergo. This research uses mixed methods research, which is a combination of qualitative and quantitative research. The research was conducted at IAIN Takengon Central Aceh, IAIN Ponorogo East Java, University of Muhammadiyah Kupang, and IAIN Samarinda. The data collection technique used an open questionnaire distributed via a google form. Analysis of the data used is qualitative and quantitative analysis. Qualitative analysis is used to analyze the reasons for students in online lectures. In contrast, quantitative analysis is used to analyze students' opinions who are happy or not with online lectures by percentage. The results showed that at IAIN Takengon $24.6 \%$ of students who liked to study online were happy. In comparison, $75.4 \%$ of those who were not happy, at IAIN Ponorogo who liked to study online were $35.8 \%$ and $64.2 \%$ who were not happy, at the University Muhammadiyah Kupang who like online lectures are $40 \%$. Those who are not happy are $60 \%$, and at IAIN Samarinda who like online lectures are $19.8 \%$ who are not happy at $80.2 \%$. Overall, new students who enjoy studying online are $30.05 \%$, and those who are not happy are $69.95 \%$.

\begin{abstract}
Abstrak
Mahasiswa baru tahun akademik 2020/2021 merupakan mahasiswa yang belum pernah merasakan pertemuan langsung dengan pihak kampus, sejak mendaftar, menjalani masa orientasi dan perkuliahan semua dilakukan secara daring. Penelitian ini bertujuan untuk mengetahui pendapat mahasiswa baru program studi Pendidikan Agama Islam terhadap perkuliahan yang dijalani. Penelitian ini menggunakan metode penelitian mixed methods, yaitu gabungan antara penelitian kualitatif dengan kuantitatif. Penelitian dilakukan di IAIN Takengon Aceh Tengah, IAIN Ponorogo Jawa Timur, Universitas Muhammadiyah Kupang, dan IAIN Samarinda. Teknik pengumpulan data menggunakan angket terbuka yang disebarkan melalui google form. Analisa
\end{abstract}

\footnotetext{
${ }^{1}$ IAIN Takengon, Aceh, Indonesia

Email: fauzansuwarno11@gmail.com

${ }^{2}$ IAIN Takengon, Aceh, Indonesia

3 IAIN Ponorogo, Ponorogo, Indonesia

4 Universitas Muhammadiyah Kupang, Kupang, Indonesia

5 IAIN Samarinda, Samarinda, Indonesia
} 
data yang digunakan adalah analisa kualitatif dan kuantitatif. Analisa kualitatif digunakan untuk menganalisa alasan mahasiswa dalam perkuliahan daring, sedangkan analisa kuantitatif digunakan untuk menganalisa pendapat mahasiswa yang senang atau tidak perkuliahan daring dengan cara prosentase. Hasil penelitian menunjukkan bahwa di IAIN Takengon mahasiswa yang senang kuliah daring sebesar $24,6 \%$ sedangkan yang tidak senang 77,4\%, di IAIN Ponorogo yang senang kuliah daring sebesar 35,8 \% dan yang tidak senang sebesar 64,2\%, di Universitas Muhammadiyah Kupang yang senang kuliah daring sebesar $40 \%$ dan yang tidak senang sebesar $60 \%$, dan di IAIN Samarinda yang senang kuliah daring 19,8\% yang tidak senang sebesar $80,2 \%$. Secara keseluruhan mahasiswa baru yang senang kuliah daring sebesar 30,05\%, dan yang tidak senang sebesar $69,95 \%$.

\section{INTRODUCTION}

The world was shocked by the outbreak of the coronavirus or often called covid-19, which infects humans in the Wuhan Province of China. This virus spread so fast that the Chinese government carried out a regional quarantine at that time. People in the Wuhan area are not allowed to leave Wuhan, and people from outside Wuhan are not allowed to enter the Wuhan area. This policy was taken to prevent the spread of the virus outside the region. In December 2019, a local outbreak of pneumonia of an initially unknown cause was detected in Wuhan (Hubai, China). It was quickly determined to be caused by a novel coronavirus, namely severe acute respiratory syndrome coronavirus 2 (SARS-CoV-2) (Dong et al., 2020). On January 30, 2020, the Word Health Organisation (WHO) Emergency Committee declared a global health emergency based on growing case notification rates at Chinese and international locations (Poluakan et al., 2019; Velavan \& Meyer, 2020)

The impact of covid-19 is so great that since it was declared a pandemic on March 22, 2020, many countries have implemented a lockdown policy to prevent the transmission of covid-19, almost all important sectors have been stopped. In the economic sector, for example, the community began to be limited in conducting economic transactions. In the tourism sector, many tourist attractions have been closed to break the spread of COVID-19. The religious sector is also an affected sector from Covid-19. The Indonesian government has also temporarily closed mosques for worship activities. In 2020, many mosques are prohibited from carrying out Eid al-Fitr and Eid al-Adha prayers. Even the most significant impact of this sector is the postponement of the departure of prospective pilgrims Hajj 2020. Likewise with the education sector.

The Indonesian government has implemented the Large-Scale Social Restrictions (PSBB) rules that were made to control the spread of Covid-19, with the hope that the virus does not spread wider and healing efforts can run optimally. In this social restriction effort, the Indonesian government has limited activities outside the home, such as educational activities from the level of Early Childhood Education (PAUD) to Higher Education which is carried out online (in the network) through online learning since March 2020, which refers to the circular letter of the Minister of Education and Culture. Number 4 of 2020 (Circular of the Minister of Education and Culture, 2020). With a circular based on the circular of the Minister of Education, finally, in 2020 all learning activities in schools and universities are carried out online, even at the beginning of the new academic year or the 2020/2021 academic year, many new students and new students are accepted online to avoid crowds, continues re-registration, orientation and learning periods are also conducted online.

This online lecture is not new in Indonesia because long before the coronavirus, until the minister's circular was issued to conduct online learning, we already know the Open University, which is conducted with Distance Lectures (PJJ). This understanding of distance is limited by location, but it can be interpreted that education is not carried out face-to-face (Wahyono et al., 2005). However, in other universities, distance learning is still rarely done institutionally, even though lecturers may do it personally. These include IAIN Takengon, IAIN Ponorogo, University of Muhammadiyah Kupang, and IAIN Samarinda. So that at the campus, online lectures are still 
looking for the ideal format so that students can attend optimal lectures and gain knowledge that is by their choice of the study program-considering that there are many problems in various universities.

Some researchers have conducted a study about online learning. For example, the problem of an unstable internet network can disrupt the course of online lectures. Gultom (2020) stated that students are students who come from various regions, and some are from the district or outside the city of Medan. So that is getting access to the internet network, each student is different. Another problem is that lecturing activities become ineffective. Not to mention the unstable network disturbance. Students who live in remote places can feel this because it is difficult to find a good internet connection. When the lecture activities started, the intention to learn had accumulated, but the mood eventually decreased due to the unsupportive network. (Rasyida et al., 2020). As for the effectiveness of online lectures, as stated by Widiyono (2020), understanding of online lectures during the Covid-19 pandemic shows that students who do not understand the material are huge, namely $75.81 \%$, for students who understand the material are $15.59 \%$, and $8.60 \%$ of students who do not understand the material. With these results, we can conclude that the online lecture process during the Covid-19 outbreak is less effective due to students' lack of understanding.

In this study, the researchers wanted to know the response of students. Especially students of the Islamic Religious Education (PAI) in four campuses, namely one campus in Java and three outside Java, to get a broader picture of the reasons students like or dislike online lectures so that the results of this study are expected to be used for policymaking for related parties.

\section{METHODS}

This study uses the Mixed Method research method, which is a combination of qualitative and quantitative research. Mixed methods research is a research design with philosophical assumptions as well as an inquiry method. As a methodology, this mixed research involves guiding philosophical assumptions direction of data collection and analysis and processing qualitative and quantitative research approaches in many phases of the research process. As a method, mixed research focuses on collecting, analyzing, and mixing qualitative and quantitative data in a single study or series of studies. The main reason for using a combination of qualitative and quantitative approaches is to understand better the research problem than using a single approach (Samsu, 2017). Data collection was carried out using an open questionnaire distributed to new students of the PAI study program. The questionnaire was distributed through the WhatsApp group application in a google form to be filled out by students. Analysis of the data used is qualitative and quantitative analysis. Qualitative analysis is used to analyze the reasons for students in online lectures. In contrast, quantitative analysis is used to analyze the opinions of students who are happy or not with online lectures by percentage.

\section{FINDINGS AND DISCUSSION}

New students of the PAI study program at IAIN Takengon in the 2020/2021 academic year amounted to 62 students, while those who filled out a questionnaire in a google form were 57 students. Of these, 14 students liked online lectures, while 43 students were bored with online lectures. The percentage of those who like online lectures is $24.6 \%$, and those who do not like it are $75.4 \%$. These data can be described in the following diagram. 


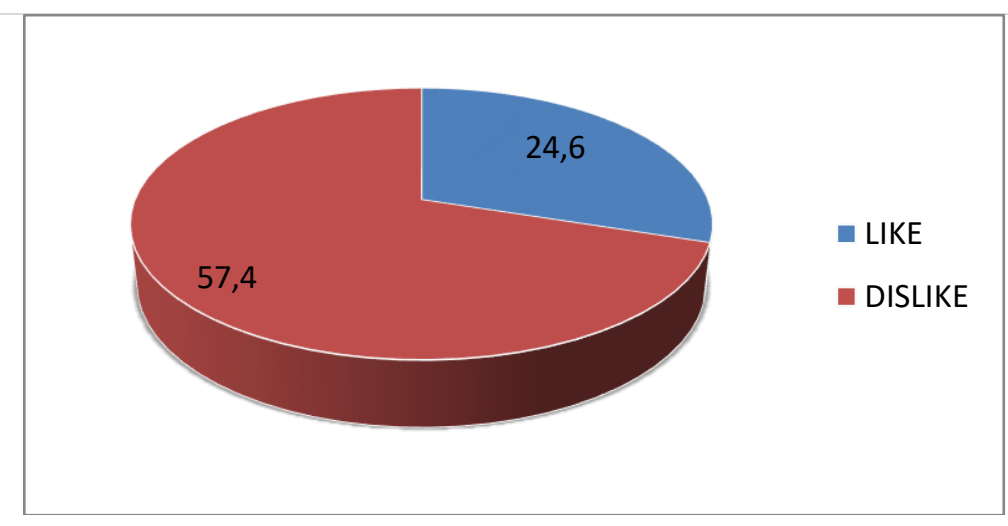

Figure 1. Percentage of Students in online college

Students who like online lectures are very religious, among others, believe that online lectures are comfortable and practical. Others say that a student whose house is far from campus, which is helped easily and can gather with family. Then some say online lectures are beneficial during Covid-19, so people are safer from being infected with the coronavirus. Some argue that online lectures can be more patient in doing college assignments or homework or other things. Then some think that online lectures are fun, flexible, efficient, short, practical, fast, precise, safe, easy, timesaving, energy-saving. Then there are other opinions that online lectures better understand how to use technology or applications before they do not quite understand.

Those are, among others, the opinions of students who are happy with online lectures at IAIN Takengon. In contrast, those who are not happy with online lectures argue that a lot of material cannot be understood. It has an impact on the final exam. A lot of lecture material is left behind. There is another reason that it is challenging to read. Understandable, sometimes the network is so tricky that it hinders lectures, especially lectures that use zoom. Another opinion says they do not get knowledge during online lectures because the knowledge delivered by lecturers directly is certainly faster for students to understand. Then another reason is that they cannot meet with friends and it is difficult to respond to the lessons given by the lecturer. That is one of the reasons why PAI IAIN Takengon students do not like online lectures. There were 341 new students of the PAI (Islamic education) IAIN Ponorogo study program for the 2020/2021 academic year who filled out student response questionnaires in online lectures and 120 students. Of the 120 students who are happy with online lectures, 43 students, and 77 students who are not, $35.8 \%$ of students are happy with online lectures, and $64.2 \%$ are not happy with online lectures. These data can be described in the following diagram:

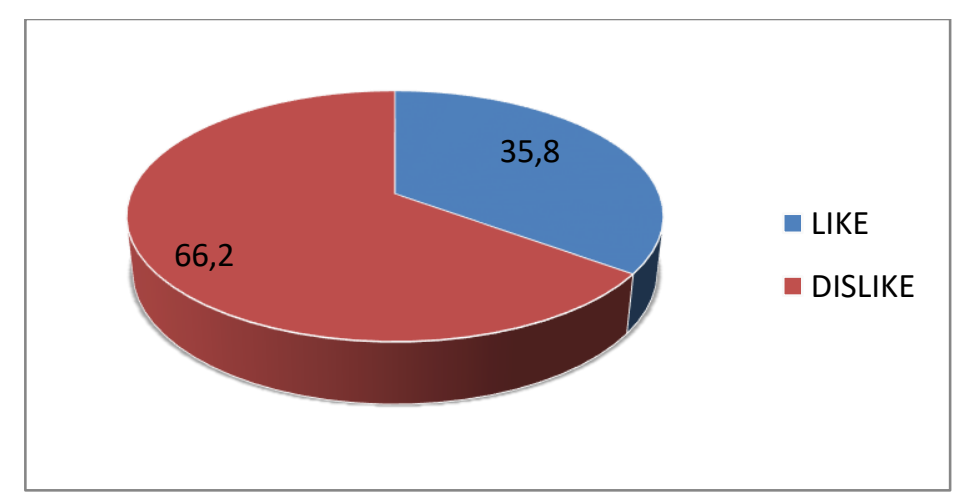

Figure 2. Percentage of IAIN Ponorogo students in online lectures

There are several opinions of students who like online lectures and those who don't like online lectures. Those who like online lectures have several opinions, including the arena with online 
lectures that they can get to know the applications used in online lectures, it can also be interspersed with work. Others think that they have free time for other valuable activities with this online lecture. After the lecture is over, the remaining time can be used for valuable things. Online learning like this, in their opinion, is fun and quite effective. Another opinion says that in addition to being required to be independent in understanding the material independently without the guidance of an influential lecturer, they can also carry out tasks more casually but seriously. Then some think that because online lectures can help the students learn lessons from campus, this makes them learn about a lot of Islamic history, such as Muhammad Al Fatih's books. Beyond the Inspiration, because they like to read with this, students can learn more. They were mastering the knowledge of subjects from campus and outside the campus. Then some think that online lectures are quite fun because they can increase knowledge and understanding about the use of online learning media and technologies that are still a new experience for them. Besides, they can also help parents.

Then, students who do not like online lectures for several reasons. Such as online lectures are boring because there are several obstacles, namely wasteful quotas, access to limited facilities such as libraries, the interaction between other students is not optimal because only through WhatsApp and other social media. Others think that if they want to ask questions, they are confused, sometimes some do not understand, and if it is just through electronic means, they cannot freely accept courses. Another opinion says that it is more effective to study with a face-to-face system if online many of the students do not understand the material being taught and are constrained by quotas. Some even argue that online lectures are the same as college and non-college. The knowledge is very minimal that can be understood, and only made assignments, and sometimes we do not understand. Another opinion is that the delivery of material is lacking and difficult to understand. Moreover, if there is a group presenting, not all students in the same class participate in the discussion, only some of them. In addition, some think that online lectures are boring because assignments are used as a reference for someone's understanding even though it is not necessarily after being given the task to increase student understanding, the learning that takes place therefore online learning limits the scope of student movement because one's understanding is not only obtained by assignments, it can be from practice in the field.

There were 42 new students of the PAI study program at the Muhammadiyah University of Kupang who filled out a google form questionnaire as many as 40 students. A total of 16 students liked online lectures, and 24 students did not like online lectures. As a percentage, $40 \%$ of students like online lectures, and 60\% do not like online lectures. From these data can be described as the following diagram:

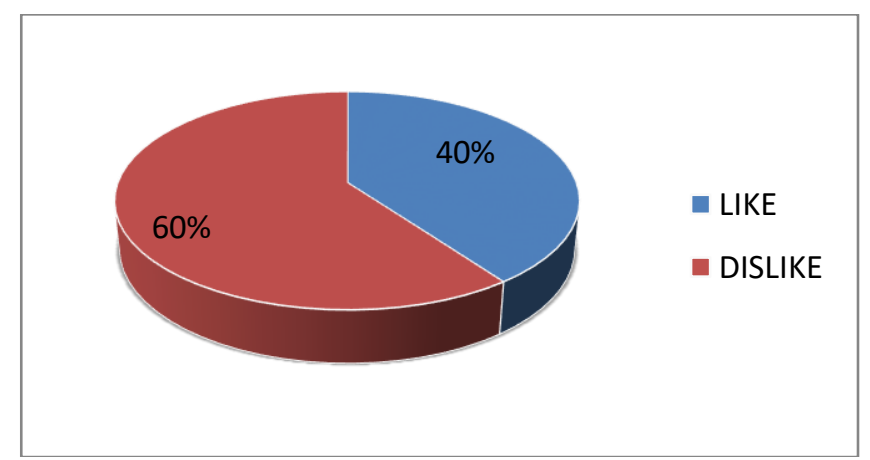

\section{Figure 3. Percentage of online lectures at the University of Muhamadiyah Kupang}

Students like online learning include being afraid of being exposed to a virus that is now being discussed a lot, namely the corona. Other opinions say because we do not need to go to campus. Even the atmosphere of the lectures is also much more relaxed and not burdened. Some argue that online lectures are not complicated because we can study anywhere. Then there are students' opinions that they still get material through zoom or classroom with distance lectures. 
Meanwhile, for those who do not like online learning for reasons, online lectures are boring because in terms of internet quota and network, if we as students are overwhelmed with internet quota or the network is slow. Then we most likely do not take the course. Another opinion says that online lectures are only focused on cellphones or laptops. The students cannot communicate directly with lecturers or friends, which makes them bored. Others think online lectures for students are monotonous, only learning and studying, while lecturers as teachers do not function because the lecturer does not explain the material given and burdens students who cannot afford to buy credit. In addition, some argue that the material presented makes students bored quickly, and online lectures make students less understanding of the material presented. Those are some of the opinions of new students of the PAI study program at the Muhammadiyah University of Kupang in online learning.

New students of the PAI study program for the academic year 2020/2021 IAIN Samarinda totaled 248 students. One hundred sixteen students filled out the google form questionnaire. Twenty-three students liked online lectures, while 93 students did not like them. Thus, the percentage of students who like online lectures is $19.8 \%$, and those who do not like it are $80.2 \%$. From the data above, it can be described as the following diagram:

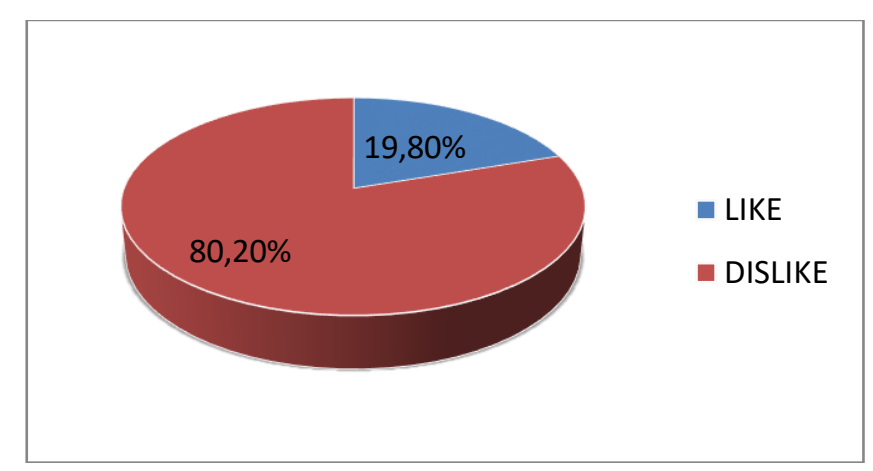

\section{Figure 4. Percentage of online lectures for new students of PAI IAIN Samarinda}

The reasons new students of the PAI study program at IAIN Samarinda like online lectures are because they do not like crowds, so they prefer online lectures. Another reason is that the students can save on transportation costs because out of town from the lecture area and only need money for the internet, especially during this pandemic where they have to stay at home to avoid the outbreak. Others think online lectures can be relaxing at home, it can be anytime, and at home, it does not make it challenging to get ready to go to campus. Another opinion is that they spend more time at home and can help their parents let alone work. In addition, there is also an opinion that online lectures can help prevent pandemic transmission, fast access to various locations, and save time.

Then some of the reasons they do not like online lectures include because they cannot interact directly and are often constrained by unstable networks. Other reasons are lack of socializing with classmates, awkward appearing in lectures, either zoom or WhatsApp. Others argue that the knowledge transfer process is less effective because there is minimal interaction, eyes are tired from staring at cellphone and laptop screens. Another opinion is that in lectures every day only through zoom or WA, only listening to the material there is no practice, so it is difficult to understand the material being taught. In addition, some argue that the little knowledge gained because they do not have direct contact with the lecturers makes limited questions. The next reason is not listening or hearing well, especially if the signal is bad and the sound and picture are broken, making the students feel bored and lazy to study.

From the data above, new students for the 2020/2021 academic year of PAI study programs from IAIN Takengon, IAIN Ponorogo, University of Muhammadiyah Kupang and IAIN Samarinda as a whole who like online lectures are 30.05\%, while those who don't like online lectures are $69.95 \%$. So it can be illustrated in the following diagram: 


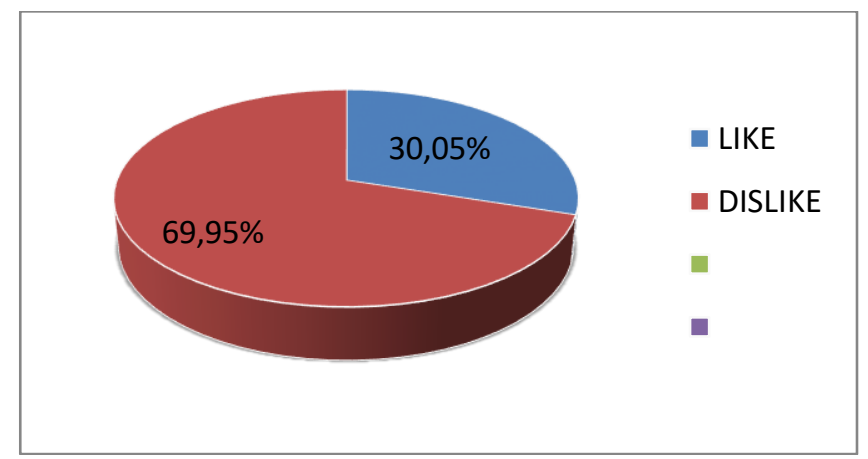

Figure 5. Percentage of new student responses in online lectures

The data above shows that the number of students who do not like online lectures is more than those who like online lectures. This should be a future evaluation. However, the pandemic condition is still ongoing, so it is not yet possible for face-to-face lectures, so what is most likely at this time to answer student complaints, especially those who do not like online lectures, is to develop a clear format for online lectures that can be controlled by all parties, namely institutions, students and people. Students' parents so that students can receive their rights to the fullest. As stated in Article 109 paragraph 1b, government regulation number 60 of 1999 states that: students have the right to get the best teaching and academic services according to their interests, talents, hobbies, and abilities (Government Regulation No. 60 of 1999, 1999) In addition, what needs to be considered is the learning strategy, institutions or lecturers can carry out various learning strategies so that lectures during the Covid-19 period can run optimally, can be combined online and face-to-face. M Fauzi explained in his research that online learning interactions are carried out independently by utilizing information technology, and learning materials have been prepared electronically. Face-toface interactions are carried out at mutually agreed times and are facilitated by a mentor (Sahudra et al., 2021). To realize a combined online mode, the campus leadership divides all students into two groups, online and offline groups. Students are given two choices through their respective tutors to take lecture options (Fauzi et al., 2020). Besides that, the students can also conduct lectures with various applications according to your needs, such as in Ferawati's research. The application used is E-mail. Learning Ubhara Jaya and Google Classroom as a place to send materials and attendance and student discussion.(Puspitorini, 2020)

Then to overcome the limitations of the material received by students, we should provide digital literacy so that students are smarter. The use of digital media among teenagers is something that cannot be separated anymore. Almost 90\% of social media users among students are connected to the digital world of Facebook, Instagram, WhatsApp Messenger, which cannot be separated from students' daily activities.(Amelia \& Ulumu, 2019). Digital literacy is the ability to use information and communication technology to find, evaluate, create, and communicate information, which requires cognitive and technical skills (Ade Dwi Nurrizqi, 2020). Based on the percentage of students' social media ownership, it can be seen that the dominant students have social media WhatsApp, Facebook, and Instagram, with the respective percentages being 97.3\%, 94.6\%, and $89.2 \%$, respectively. It shows that WhatsApp is the highest social media application owned by students. While the lowest social media ownership is on websites/blogs with a percentage of only 21.3\%.(Hendra Nelva Saputra1, 2020). Thus, we need to provide students with digital literacy so that the lack of online lecture materials can be resolved.

\section{CONCLUSION}

The perception of new students for the 2020/2021 academic year is very diverse. Some students are like online lectures about 30.05\%. Those who do not like it are $69.95 \%$. The reasons are 
given between those who like it and those who do not like it also vary, those who like it, in general, are for reasons of being able to relax, being able to help their parents, saving costs for those who are far away, not needing boarding and transportation. Then those who do not like it in general because the quota is expensive, the network is not good, the lecture material is lacking. All interested parties should think of a clear format for online lectures. Students do not like online lectures should be considered in determining policies, how to deal with bad networks, how to overcome internet quotas that students have to bear, and how to provide maximum lecture materials.

\section{REFERENCES}

Ade Dwi Nurrizqi, R. R. (2020). Tingkat Literasi Digital Mahasiswa Jurusan Ilmu Perpustakaan Dalam Pemanfaatan E-Resources Uin Raden Fatah Palembang Ade. Pustakaloka:Jurnal Kajian Informasi Dan Perpustakaan, 12(1), 72-89.

Amelia, D. J., \& Ulumu, B. (2019). Literasi Digital di Kalangan Mahasiswa PGSD Universitas Muhamamdiyah Malang. Edumaspul: Jurnal Pendidikan, 3(2), 106-111.

Dong, E., Du, H., \& Gardner, L. (2020). An interactive web-based dashboard to track COVID-19 in real time. The Lancet Infectious Diseases, 2O(5), 533-534. https://doi.org/10.1016/S14733099(20)30120-1

Fauzi, M., Al, S., \& Bangkalan, I. (2020). Strategi Pembelajaran Masa Pandemi Covid-19. Al-Ibrah, 2(2), 120-145.

Gultom, C. R., \& Sitanggang, S. G. M. (2020). Persepsi Mahasiswa Unika Terhadap Kuliah Online Di Masa. Persepsi Mahasiswa Unika Terhadap Kuliah Online Di Masa Pandemi Covid 19, 3, 7.

Hendra Nelva Saputra1, S. (2020). Potret Sikap Mahasiswa dalam Penggunaan Literasi Digital. Jurnal Komunikasi Pendidikan, 4(2), 94-101.

Peraturan Pemerintah no 60 tahun 1999, (1999).

Poluakan, M. V., Dikayuana, D., Wibowo, H., \& Raharjo, S. T. (2019). Potret Generasi Milenial pada Era Revolusi Industri 4.o. Focus: Jurnal Pekerjaan Sosial, 2(2), 187-197.

Puspitorini, F. (2020). Strategi Pembelajaran Di Perguruan Tinggi Pada Masa. Jurnal Kajian Ilmiah (JKI), 1(1), 99-106.

Rasyida, H., Kedokteran, F., \& Mangkurat, U. L. (2020). Efektifitas Kuliah Daring dimasa Pandemik. Edukasi, 1(November), 1-8.

Sahudra, Tengku Muhammad., Taher Alamsyah., Kemal, Isthifa. (2021). E-Learning Development Management With The Schoology Improving Geographic Learning Literation. Journal of Eduction Technology, 5 (1), pp. 70-75. http://dx.doi.org/10.23887/jet.v5i1.33631

Samsu. (2017). METODE PENELITIAN : Pusaka.

surat edaran Menteri Pendidikan dan Kebudayaan. (2020). 1-3.

Velavan, T. P., \& Meyer, C. G. (2020). The COVID-19 epidemic. Tropical Medicine and International Health, 25(3), 278-280. https://doi.org/10.1111/tmi.13383

Wahyono, E., Setijadi, \& Suratinah. (2005). Pendidikan jarak jauh pada jenjang Pendidikan Tinggi. Pendidikan )Arak)Auh, 50.

Widiyono, A. (2020). Efektifitas Perkuliahan Daring (Online) pada Mahasiswa PGSD di Saat $\begin{array}{llll}\text { Pandemi Covid } 19 . & \text { Jurnal Pendidikan, 8(2), 169-177. }\end{array}$ https://doi.org/10.36232/pendidikan.v8i2.458 